\title{
The Effect of Capital Adequacy and Liquidity on Profitability in Food and Beverage Sub Sector Manufacturing Companies Listed on the Indonesia Stock Exchange (ISE) Period 2015-2018
}

\author{
Irma Melani ${ }^{1}$, Suroso ${ }^{2}$, Nurul Musqori ${ }^{3}$ \\ ${ }^{1}$ Financial Management at Ibn Chaldun University, Jakarta \\ ${ }^{23}$ Faculty of Economics, Ibn Chaldun University, Jakarta \\ Correspondent: irmaamelanii@gmail.com
}

Submitted: 3 August 2019. Revised: 27 August, 14 Sept 2019. Published: 30 October 2019.

\begin{abstract}
This study aims to analyze the effect of the independent variables on the dependent variable. The independent variables are Capital Adequacy (CAR) and Liquidity (CR) while the dependent variable is Profitability (ROA) in Food and Beverage Sub-Sector Manufacturing Companies Listed on the Indonesia Stock Exchange (ISE) for the period of 2015-2018. The sample in this study consisted of 8 companies listed on the Indonesia Stock Exchange (ISE) for 4 years in the 20152018 period. The data used in this study is to use the company's financial statement data published on the Indonesia Stock Exchange (ISE) website and the official website of each company. The data used are secondary data and the method used is panel data regression analysis with the help of the Eviews 9 program to obtain a comprehensive picture of the relationship between one variable with another variable. The results showed that CAR significantly influenced ROA, CR did not influence significantly ROA, CAR and CR simultaneously had an effect on ROA. The effect of CAR and CR on ROA of $92.47 \%$ while the remaining $7.33 \%$ is influenced by other factors not included in the research model.
\end{abstract}

Keywords : BEI (ISE), CAR, CR, ROA, Data Panel

\section{INTRODUCTION}

ISE or the Indonesia Stock Exchange is a capital market in Indonesia. Until now there are six hundred companies incorporated on the ISE. The companies are divided into several industrial sectors, one of them is the manufacturing industry. Manufacturing companies are companies that process raw materials into goods ready for sale. All processes that occur in this industry generally involve facilities such as land, factories, machinery, transport vehicles and other supporting facilities.

The manufacturing industry is an industry that dominates companies listed on the Indonesia Stock Exchange (ISE). The number of companies in the industry as well as the current economic conditions, their performance have created a tight competition among manufacturing companies. Competition in the manufacturing industry makes each company improve its performance so that its goals can be achieved.

All manufacturing companies in Indonesia in the era of globalization should try to produce high quality goods at low cost in order to increase competitiveness in both the domestic and global markets. Every company registered at PT. Indonesia Stock Exchange (ISE) wants the price of 
The Effect of Capital Adequacy and Liquidity on Profitability in Food and Beverage Sub Sector Manufacturing Companies Listed on the Indonesia Stock Exchange (ISE) Period 2015-2018

Melani, Suroso, Musqori

shares sold to have high potential prices and attract investors to buy them. This is because, the higher the stock price, the higher the value of the company.

The rapid development of the number of manufacturing companies is not or has not been supported by close supervision, this has caused many problems in the manufacturing world such as misuse of lending which eventually becomes bad credit, this is resulting the manufacturing company becoming severely short of liquidity, which in turn makes the company bankrupt (liquidated).

As it is well known that manufacturing companies are industries which in their activities rely on capital from investors, therefore manufacturing companies must be able to maintain their financial health or liquidity. Considering the magnitude of the effect that arises when financial difficulties occur in the manufacturing industry, it is necessary to analyze in such a way that financial distress and the possibility of bankruptcy can be detected early to further determine the direction of policy. To increase liquidity, by increasing working capital. However, this policy will result in a reduction in sales volume. Therefore, companies must reach a balance between liquidity and profitability (Vishnani \& Shah, 2007).

The consumer goods are an important industry for the development of the nation's economy. This is inseparable from the companies engaged in the consumer goods industry in Indonesia. It is undeniable that in the process of producing the consumer goods, many resources are needed including human resources. The consumer goods industry has a role in absorbing labor and increasing income in a country. Food and beverage companies are one of the industrial sector categories on the Indonesia Stock Exchange (IDX) that have the opportunity to grow and develop and are a company engaged in the manufacture of products and then sold to obtain large profits. The food and beverage industry is predicted to improve its condition. This is seen increasingly mushrooming food and beverage industry in this country, especially since entering into a prolonged crisis. This condition makes the competition even tighter so company managers are competing to find investors to invest their funds in the food and beverage companies.

Food and beverage companies must be able to maintain their financial performance in order to achieve a goal that has become the basis of the company. The company's financial performance is a picture of the company's financial condition which is analyzed by financial analysis tools.

Capital is one of the foundations that is needed in a company that has the potential to have the risk of any credit or productive assets. Capital has a function as the main source of financing for operational activities. To ensure that the consumer goods industry has sufficient capital to support its business activities, the regulatory authority is responsible for determining the minimum amount of capital that must be owned by issuing provisions regarding minimum capital.

Every company definitely needs working capital to buy daily needs. Working capital is closely related to the company's current assets. Working capital management is an important aspect for the company. If the company lacks assets to develop its products and services, while consumer demand is greater, then the company will lose consumers because they are unable to meet the needs of these consumers.

The amount of current assets or working capital cannot be used as a benchmark to get a large profit in a company, because in a company that has current assets or large working capital, the profit will not necessarily be large. However, profit is very dependent on working capital while working capital is very dependent on the value of accounts receivable turnover and inventory turnover. Working capital will increase and has a positive value if the value of turnover is high. 
The Effect of Capital Adequacy and Liquidity on Profitability in Food and Beverage Sub Sector Manufacturing Companies Listed on the Indonesia Stock Exchange (ISE) Period 2015-2018

Melani, Suroso, Musqori

Capital Adequacy Ratio (CAR) is a measure of company performance, by knowing the CAR of a company, it can determine the performance of the company concerned. CAR can also be a capital appraiser in a company because capital is an important factor for the company in the context of developing its business so that the CAR can be used as an appraisal tool for investment decisions for companies that issue shares through the company's financial condition and achievements as reflected in its financial statements. Once the importance of capital for the company, the manager is often faced with the choice to meet and maintain the adequacy of its capital, because capital is an important factor in business development and accommodate losses. Capital adequacy ratio shows the ability of banks to overcome losses (Jeslin Sheeba, 2017).

This research emphasizes more on liquidity ratios and profitability ratios. Liquidity ratios are ratios that illustrate the ability of a company to meet its short-term obligations that are due soon. This ratio is very important because the company's failure to meet its debt / short-term obligations will lead the company towards bankruptcy. The measurement of liquidity ratios used in this study is the Current Ratio (CR). Current Ratio is the ratio of current assets to current liabilities. This is the most common method used to test liquidity and measure a company's ability to pay its shortterm debt (Agha, 2014).

Profitability is the company's ability to make a profit. Profitability is also an indicator of a company's ability to meet obligations for its funders and is an element in creating company prospects in the future (Dewi \& Wirajaya, 2013). The level of profitability of the company, is very important to assess the financial performance of a company. Every company would want a high profitability in order to maintain the stability of the liquidity of the company. In addition, if a company's profitability is always good, this can affect the number of investors who want to invest or plant shares in the company.

Profitability ratios are ratios used to assess the ability of a company to look for profits. This ratio also reflects the level of effectiveness of company management which can be seen from the profits generated through sales and investment income. The higher the profitability of a company, the company's ability to generate profits also increases. In general, the value of a company's profitability can be used as an indicator to measure the performance of a company. Profitability in this study was measured using Return On Assets (ROA) (Sofyan, 2019). The profitability ratio also plays an important role in the company's financial position. Each stakeholder has an interest in the company's liquidity position. The supplier of the goods will check the company's liquidity before selling the goods on credit. Employees must also care about the company's liquidity to find out whether the company can fulfill obligations related to its employees - salaries, pensions, reserve funds, etc. Thus, the company needs to maintain adequate liquidity so that liquidity greatly affects earnings where some of the portion will be shared with shareholders. Liquidity and profitability are closely related because one increases the other decreases (Saleem \& Rehman, 2011).

The results of previous studies show that simultaneous current ratio (CR), quick ratio (QR), cash ratio, gross profit margin, return on assets, and return on equity have a significant effect on earnings growth. Partially, the six independent variables did not have a significant effect on the profit growth of the manufacturing companies in the food and beverage sector listed on the Indonesia Stock Exchange during the period 2010-2012 (Khaldun, Utara, Muda, \& Utara, 2014). The capital adequacy ratio was found to have a positive and significant relationship to profitability (Akhtar, Ali, \& Sadaqat, 2011). Current Ratio (CR), Debt to Assets Ratio (DAR), Primary Ratio (PR), and Number of Borrowers (JP) jointly influence the level of profitability with the proxy of 
The Effect of Capital Adequacy and Liquidity on Profitability in Food and Beverage Sub Sector Manufacturing Companies Listed on the Indonesia Stock Exchange (ISE) Period 2015-2018

Melani, Suroso, Musqori

UPK-SPP Return on Assets (ROA) indicator. Partially, the financial performance of UPK-SPP Current Ratio (CR) and Primary Ratio (PR) does not significantly influence the level of profitability (ROA) of UPK-SPP. But social performance with the Indicator Number of Borrowers (JP) that partially affects the level of profitability (ROA) of UPK-SPP (Darmayanti, Tarumun, \& Rifai, 2019). CR, DER and Sales Growth have no significant effect on profitability (Barus \& Leliani, 2013).

\section{METHOD}

The research method used in this study is a descriptive analysis method with a quantitative approach that is by finding information about the symptoms that exist, clearly defined objectives to be achieved, planning how to approach it, collecting data as material for making reports. The use of this quantitative descriptive method is harmonized with the research variables which focus on the actual problems and phenomena that are happening now with the form of the results of the research in the form of numbers having meaning. The research variables that will be examined in this study are divided into two main variables, namely the independent variable $(\mathrm{X})$ which consists of three variables, namely $\mathrm{CAR}\left(\mathrm{X}_{1}\right)$ and $\mathrm{CR}\left(\mathrm{X}_{2}\right)$ while the dependent variable $(\mathrm{Y})$ is ROA. Quantitative approach is an approach used in research by measuring indicators of research variables in order to obtain an overview between these variables.

The purpose of this study is to determine the effect of capital adequacy on profitability, to determine the effect of liquidity on profitability, and to determine the effect of capital adequacy and liquidity together on profitability.

Based on records on the Indonesia Stock Exchange (ISE) as of April 2019 there were 26 listed food and beverage sub-sector manufacturing companies, but researchers will examine the 8 companies shown in table 1.1.

Table 1. List of Food \& Beverage Sub-Sector Manufacturing Companies

\begin{tabular}{lll}
\hline $\mathbf{N o}$ & Code & Company \\
\hline $\mathbf{1}$ & ULTJ & PT. Ultrajaya Milk Industry and Trading Company Tbk \\
\hline $\mathbf{2}$ & MYOR & PT. Mayora Indah Tbk \\
\hline $\mathbf{3}$ & ICBP & PT. Indofood CBP Sukses Makmur Tbk \\
\hline $\mathbf{4}$ & SKLT & PT. Sekar Laut Tbk \\
\hline $\mathbf{5}$ & STTP & PT. Siantar Top Tbk \\
\hline $\mathbf{6}$ & ROTI & PT. Nippon Indosari Corpindo Tbk \\
\hline $\mathbf{7}$ & INDF & PT. Indofood Sukses Makmur Tbk \\
\hline $\mathbf{8}$ & DLTA & PT. Delta Djakarta Tbk \\
\hline \multicolumn{3}{c}{ Source: sahamok.com }
\end{tabular}

Data analysis in this study used panel data regression analysis method. Panel data is data that consists of several variables such as the cross section data, but has a time element as in the time series data. In this study using the EViews 9. program. The framework for this research is as follows: 
The Effect of Capital Adequacy and Liquidity on Profitability in Food and Beverage Sub Sector Manufacturing Companies Listed on the Indonesia Stock Exchange (ISE) Period 2015-2018

Melani, Suroso, Musqori

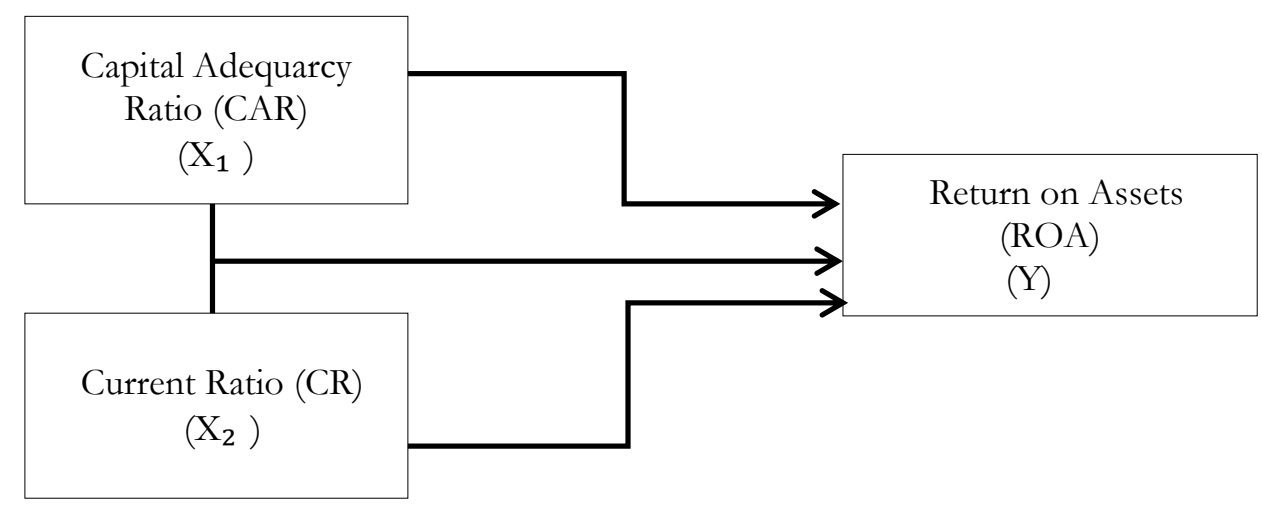

\section{RESULT AND DISCUSSION}

Table 1. Output Regresi Data Panel Model Fixed Effect Model

Dependent Variable: ROA?

Method: Pooled Least Squares

Date: 08/02/19 Time: 17:43

Sample: 20152018

Included observations: 4

Cross-sections included: 8

Total pool (balanced) observations: 32

\begin{tabular}{|c|c|c|c|c|}
\hline Variable & Coefficient & Std. Error & $\mathrm{t}$-Statistic & Prob. \\
\hline $\mathrm{C}$ & 0.122036 & 0.019256 & 6.337582 & 0.0000 \\
\hline CAR? & -0.143040 & 0.040308 & -3.548703 & 0.0018 \\
\hline CR? & 0.003115 & 0.006352 & 0.490422 & 0.6287 \\
\hline \multicolumn{5}{|c|}{ Fixed Effects (Cross) } \\
\hline _ULTJ--C & 0.069940 & & & \\
\hline _MYOR--C & -0.014589 & & & \\
\hline _ICBP--C & 0.038251 & & & \\
\hline _STTP--C & -0.026607 & & & \\
\hline _ROTI--C & -0.020602 & & & \\
\hline _INDF--C & -0.073115 & & & \\
\hline _SKLT--C & -0.055917 & & & \\
\hline _DLTA--C & 0.082639 & & & \\
\hline \multicolumn{5}{|c|}{ Effects Specification } \\
\hline \multicolumn{5}{|c|}{ Cross-section fixed (dummy variables) } \\
\hline R-squared & 0.946566 & \multicolumn{2}{|c|}{ Mean dependent var } & 0.102634 \\
\hline Adjusted R-squared & 0.924706 & \multicolumn{2}{|c|}{ S.D. dependent var } & 0.054673 \\
\hline S.E. of regression & 0.015002 & \multicolumn{2}{|c|}{ Akaike info criterion } & -5.310964 \\
\hline Sum squared resid & 0.004951 & \multicolumn{2}{|c|}{ Schwarz criterion } & -4.852922 \\
\hline Log likelihood & 94.97543 & \multicolumn{2}{|c|}{ Hannan-Quinn criter. } & -5.159136 \\
\hline F-statistic & 43.30241 & \multirow{2}{*}{\multicolumn{2}{|c|}{ Durbin-Watson stat }} & 2.044807 \\
\hline Prob(F-statistic) & 0.000000 & & & \\
\hline
\end{tabular}

The results of the above test obtained a regression coefficient of -0.143040 with a probability of 0.0018 does not exceed the significance of 0.05 which means the CAR has a negative effect on ROA. A negative regression coefficient value of -0.143040 explains that each increase in CAR by 
The Effect of Capital Adequacy and Liquidity on Profitability in Food and Beverage Sub Sector Manufacturing Companies Listed on the Indonesia Stock Exchange (ISE) Period 2015-2018

Melani, Suroso, Musqori

1\% will decrease CAR by 0.143040 assuming the other ratios are fixed. The higher CAR, the stronger the company's ability to bear credit risk where ROA will be better and can increase company profits. The results of this study are in line with research conducted by Sofyan (2019) whose results indicate that CAR negatively affects ROA. The lower the CAR, the weaker the company's ability to bear credit risk. In accordance with the theory of pecking orders where the company will first use internal funds before using external funds. Therefore management must be careful in determining funding decisions.

CR regression coefficient of 0.003115 with a probability of $0.6287>0.05$, which means no effect on ROA. A high CR value indicates that the availability of current assets to pay off current liabilities is also high. Whereas current assets contain accounts such as cash and cash equivalents, receivables, inventories and securities. However, the high CR does not guarantee that the cooperative has enough cash to fulfill its current liabilities. The results of this study are consistent with research conducted by Andreani (2013) whose results indicate that CR is not significant to ROA.

\section{CONCLUSION}

The $t$ test conducted in the study used a significance value of 0.05 and obtained a CAR of 0.0018 with a coefficient value of -0.143040 which indicates that CAR has a significant effect on ROA and has a negative coefficient value. The CR variable has a coefficient value of 0.003115 with a probability of exceeding a significance value of 0.6287 which means that $\mathrm{CR}$ has no effect on ROA.

Based on the financial data table of each company where the highest ROA in DLTA companies was 0.22194 in 2018, the highest CAR in ROTI companies was 0.517789 in 2018, and the highest CR in DLTA companies was 8.637842 in 2017 . For this reason, company management can pay attention to the Current ratio variable. This variable has no effect on Return on Assets so that management can increase total current assets and reduce current liabilities. The management should pay attention to the amount of capital owned by managing funds effectively and efficiently by channeling funds to productive assets in order to obtain optimal profits.

For other researchers, it is expected that the results of this study can then be used as a reference to study other variables besides the problem of capital adequacy, liquidity, and profitability which have been discussed by different authors and indicators and supported by latest theories or research. For the number of observations it should be added, both in terms of crosssection and time series.

\section{REFERENCE}

Agha, H. (2014). Impact of Working Capital Management on Profitability. European Scientific Journal, 10(1), 374-381. https://doi.org/10.19044/esj.2014.v10n1p\%p

Akhtar, M. F., Ali, K., \& Sadaqat, S. (2011). Factors influencing the profitability of Islamic banks of Pakistan. International Research Journal of Finance and Economics, 66, 125-132. Retrieved from http://citeseerx.ist.psu.edu/viewdoc/download?doi=10.1.1.458.8877\&rep=rep1\&type=pdf

Barus, A. C., \& Leliani. (2013). Analisis Faktor-Faktor yang Mempengaruhi Profitabilitas pada Perusahaan Manufaktur yang Terdaftar di Bursa Efek Indonesia. Jurnal Wira Ekonomi Mikroskli, 3(2), 111-121. Retrieved from https://www.mikroskil.ac.id/ejurnal/index.php/jwem/article/view/207/130 
The Effect of Capital Adequacy and Liquidity on Profitability in Food and Beverage Sub Sector Manufacturing Companies Listed on the Indonesia Stock Exchange (ISE) Period 2015-2018

Melani, Suroso, Musqori

Darmayanti, M., Tarumun, S., \& Rifai, A. (2019). Analisis Faktor-Faktor Yang Mempengaruhi Profitabilitas Unit Pengelola Kegiatan Simpan Pinjam Perempuan (UPK SPP) di Lampung Selatan. Jurnal Agribisnis, 20(2), 181-195. Retrieved from https://journal.unilak.ac.id/index.php/agr/article/view/1001/1411

Dewi, A. S. M., \& Wirajaya, A. (2013). Pengaruh Struktur Modal, Profitabilitas dan Ukuran Perusahaan Pada Nilai Perusahaan. E-Jurnal Akuntansi, 4(2), 358-372. Retrieved from https://ojs.unud.ac.id/index.php/Akuntansi/article/view/6233

Jeslin Sheeba, J. (2017). A Study on The Impact of Credit Risk on The Profitability of State Bank of India (SBI). ICTACT Journal on Management Studies, 3(2), 538-542. https://doi.org/10.21917/ijms.2017.0073

Khaldun, K. I., Utara, U. S., Muda, I., \& Utara, U. S. (2014). The Influence of Profitability and Liquidity Ratios on The Growth of Profit of Manufacturing Companies. Journal of Finance, II(12), 1-17. Retrieved from https://ijecm.co.uk/wp-content/uploads/2014/12/21215.pdf

Saleem, Q., \& Rehman, R. U. (2011). Impacts of liquidity ratios on profitability. Interdisciplinary Journal of Research in Business, 1(7), 95-98. Retrieved from http://journaldatabase.info/articles/impacts_liquidity_ratios_on.html

Sofyan, M. (2019). Faktor-Faktor Yang Mempengaruhi Profitabilitas Bank Perkreditan Rakyat (BPR) di Provinsi Jawa Timur. Jurnal Inspirasi Bisnis Dan Manajemen, 3(1), 63-76. https://doi.org/10.33603/jibm.v3i1.2093

Vishnani, S., \& Shah, B. K. (2007). Impact of Working Capital Management Policies on Corporate Performance-An Empirical Study. Global Business Review, 8(2), 267-281. https://doi.org/10.1177/097215090700800206 